\title{
Hubungan Kualitas Tidur dengan Kualitas Hidup Lansia dengan Penyakit Diabetes Mellitus Tipe 2
}

\author{
Berthiana, Wijaya Atmaja Kasuma \\ Poltekkes Kemenkes Palangka Raya, Jl. George Obos No. 30, 32, Menteng, \\ Kecamatan Jekan Raya, Kota Palangka Raya, Kalimantan Tengah \\ Email: berthiana@poltekkes-palangkaraya.ac.id
}

$\begin{array}{ll}\text { Diterima tanggal } & : \text { 18 Februari } 2020 \\ \text { Direvisi tanggal } & : 8 \text { Maret 2020 } \\ \text { Dipublikasikan tanggal } & : \text { 11 Juni 2020 }\end{array}$

\begin{abstract}
Abstrak
Latar Belakang dan Tujuan: Salah satu tanda dan gejala Diabetes Mellitus (DM) yaitu sering buang air kecil dalam jumlah banyak pada malam hari sehingga berdampak pada kualitas tidur. Tidur yang efektif pada pasien DM sangat dibutuhkan untuk memperbaiki sel-sel yang rusak termasuk sel beta yang berfungsi untuk memproduksi insulin. Tujuan penelitian ini untuk mengetahui hubungan kualitas tidur dengan kualitas hidup pada lansia dengan penyakit DM tipe 2.

Metode: Desain penelitian menggunakan deskriptif korelasi dengan pendekatan cross sectional. Penelitian ini dilakukan di Prolanis Sanang Barigas Palangka Raya. Jumlah responden yaitu 33 responden. Teknik pengambilan data dilakukan secara simultan atau pada suatu waktu (point time approach). Analisis data menggunakan uji Chi Square.

Hasil: Mayoritas responden berjenis kelamin laki-laki yaitu 20 orang (60,6\%), usia hampir seluruhnya sekitar 60-74 tahun yaitu 29 responden $(87,9 \%)$, pekerjaan mayoritas pensiunan sebanyak 20 responden $(60,6 \%)$, tingkat pendidikan paling banyak adalah lulusan SMA 15 responden $(45,5 \%)$, mayoritas kualitas tidur buruk dengan jumlah 19 responden $(57,6 \%)$, dan sebagian besar kualitas hidup buruk dengan jumlah 19 responden $(57,6 \%)$. Hasil penelitian menunjukkan terdapat hubungan yang signifikan antara kualitas tidur dengan kualitas hidup lansia dengan DM tipe 2 ( $p$-value $0,000<0,05)$.

Simpulan dan Implikasi: Kualitas tidur menentukan kualitas hidup lansia dengan penyakit DM tipe 2. Semakin buruk kualitas tidur lansia maka semakin buruk pula kualitas hidupnya. Dengan demikian intervensi lebih lanjut mengenai perbaikan kualitas tidur diperlukan untuk meningkatkan kualitas hidup lansia dengan penyakit DM tipe 2 .
\end{abstract}

Kata Kunci: Diabetes Mellitus; Kualitas hidup; Kualitas tidur; Lansia

Sitasi: Berthiana \& Kasuma WA. (2020). Hubungan kualitas tidur dengan kualitas hidup lansia dengan penyakit diabetes mellitus tipe 2. The Indonesian Journal of Health Science. 12(1), 11-16

Copyright: (c) 2020 Berthiana et al. This is an open-access article distributed under the terms of the Creative Commons Attribution License, which permits unrestricted use, distribution, and reproduction in any medium, provided the original author and source are credited.

Diterbitkan Oleh: Universitas Muhammadiyah Jember

ISSN (Print): 2087-5053

ISSN (Online): 2476-9614 


\begin{abstract}
Background and Aim: One of the signs and symptoms of Diabetes Mellitus (DM) is polyuria in large quantities at night so that it has an impact on sleep quality. Effective sleep in diabetic patients is needed to repair damaged cells, including beta cells that function to produce insulin. The Aim of this research is to determine the relationship of the quality of sleep and quality of life in older adults with type 2 Diabetes Mellitus.

Methode: This research is descriptive correlation with cross sectional approach. This research conducted in Prolanis Sanang Barigas Palangka Raya. The number of respondents were 33 respondents. Data collected retrieval techniques simultaneously or at a time (point time approach). Data were analyzed used Chi Square test.

Results: Majority of respondents were male 20 respondents (60.6\%), almost all of them are around 60-74 years old 29 respondents (87.9\%), the majority of prefession were retirees 20 respondents (60.6\%), education level most of them were high school graduates 15 respondents (45.5\%), respondents majority had poor sleep quality 19 respondents (57.6\%), and most of them had poor quality of life 19 respondents (57.6\%). The results showed that there was a significant relationship between sleep quality and quality of life in the elderly with type 2 diabetes mellitus ( $p$-value $0.000<0.05$ ).

Conclusion: Sleep quality determines the quality of life of the elderly with type 2 diabetes mellitus. The worse the quality of sleep for the elderly, the worse the quality of life. Thus, further intervention regarding the improvement of sleep quality is needed to improve the quality of life of the elderly with type 2 diabetes mellitus.
\end{abstract}

Keywords: Diabetes Mellitus; Elderly; Sleep quality; Quality of life,

\section{PENDAHULUAN}

Gangguan tidur menyebabkan berbagai gangguan seperti gangguan sistem kardiovaskular dan endokrin, serta memperberat persepsi nyeri (Al-Maskari, et.al, 2011; Chang, et.al, 2010). Empat gejala utama menandai sebagian besar gangguan tidur yaitu; insomnia, hipersomnia, parasomnia, dan gangguan jadwal tidur-bangun. Gangguan tidur membuat kualitas tidur terganggu (American Diabetic Association, 2015; Bustan, 2015). Kualitas tidur adalah kepuasan seseorang terhadap tidur, sehingga seseorang tersebut tidak memperlihatkan perasaan lelah, mudah terangsang dan gelisah, lesu dan apatis, kehitaman di sekitar mata, kelopak mata bengkak, konjungtiva merah, mata perih, perhatian terpecah-pecah, sakit kepala dan sering menguap atau mengantuk (Budiatri et al, 2013).

Berdasarkan hasil studi pendahuluan yang dilakukan peneliti pada tanggal 22 Februari 2019 di Prolanis Sanang Barigas Palangka Raya terdapat 33 lansia yang mederita diabetes mellitus. Prolanis Sanang Barigas merupakan Prolanis dengan jumlah paling banyak lansianya yang aktif dibandingkan prolanis lain. Saat peneliti melakukan wawancara didapatkan hasil 4 dari 5 lansia mengalami gangguan tidur.

Gangguan tidur yang terjadi pada penderita diabetes mellitus akan 
menyebabkan penurunan pada kualitas hidupnya. Pasien yang menderita penyakit diabetes mellitus yang menjalani terapi pengobatan dapat mempengaruhi kapasitas fungsional, psikologis dan kesehatan sosial serta mempengaruhi kesejahteraannya yang didefinisikan sebagai kualitas hidup atau quality of life (QoL) (Wimpie, 2007). Quality of Life adalah kondisi dimana pasien yang menderita penyakit yang sedang dideritanya dapat tetap merasa nyaman secara fisik, psikologis, sosial maupun spiritual serta secara optimal memanfaatkan hidupnya untuk kebahagian dirinya maupun orang lain. Rata-rata pasien penyandang diabetes mellitus umumnya mengalami gangguan kualitas tidur, dikarenakan sering terbangun diamalam hari untuk buang air kecil atau merasa haus sehingga kualitas tidurnya terganggu. Gangguan kualitas tidur tersebut jika terus berkelanjutan akan berdampak pada penurunan kualitas hidup pasien penyandang diabetes mellitus (Fitri, 2015).

Pengukuran kualitas hidup bersifat multidimensi yang meliputi fungsi fisik, psikologis, sosial, lingkungan dan kualitas hidup secara umum. Pengukuran kualitas hidup bisa dilakukan dengan menggunakan kuesioner yang dikembangkan oleh WHO (2004). Para penderita diabetes mellitus dikatakan memiliki hidup yang berkualitas apabila mereka memiliki kondisi fungsional yang optimal, sehingga mereka dapat menikmati kehidupannya dengan penuh makna, membahagiakan dan berguna. Gangguan kualitas tidur pada lansia yang menderita diabetes mellitus dapat mempengaruhi kualitas hidup lansia tersebut seperti kualitas hidup yang buruk, fisik, emosi, dan sosial. Dengan demikian maka tujuan penelitian ini untuk mengetahui apakah ada hubungan antara kualitas tidur dengan kualitas hidup lansia yang mempunyai penyakit DM tipe 2.

\section{METODE PENELITIAN}

\section{Desain penelitian}

Desain penelitian menggunakan deskriptif korelasi dengan pendekatan cross sectional. Populasi dalam penelitian adalah seluruh lansia anggota prolanis yang menderita Diabetes Melitus tipe 2 di Klub Prolanis Sanang Barigas Palangka Raya yang berjumlah 33 orang. Untuk mendapatkan populasi target diberlakukan filter menggunakan kriteria inklusi dan kriteria eksklusi. Kriteria inklusi dalam penelitian ini antara lain: lansia yang berusia 60 tahun ke atas, masih dapat berkomunikasi agar mempermudah proses penelitian, tidak mengalami gangguan pendengaran, bersedia menjadi responden. Kriteria eksklusi dalam penelitian ini antara lain: lansia yang mengkonsumsi obat tidur, lansia yang mengalami demensia. Berdasarkan kriteria inkusi dan kriteria eksklusi tersebut, maka jumlah populasi dalam penelitian ini berjumlah 33 lansia. Teknik pengambilan sampel dalam penelitian ini adalah total sampling. Jadi, karena peneliti menggunakan teknik pengambilan total sampling maka sampel dalam penelitian ini berjumlah 33 orang.

\section{Instrumen}

Kuesioner pada penelitian ini menggunakan kuesioner PSQI. PSQI adalah kuesioner yang digunakan untuk menilai kualitas tidur dan 
gangguan tidur dari seseorang. Pittsburgh Sleep Quality Index (PSQI) dikembangkan oleh The Hartford Institute for Geriatric Nursing, College of Nursing, New York University. PSQI memiliki konsisten internal dan koefisien reliabilitas sebesar 0,83 untuk ketujuh komponennya. PSQI terdiri dari 19 pertanyaan dari 7 (tujuh) komponen, yaitu kualitas tidur subyektif, latensi tidur, durasi tidur, efisiensi tidur, gangguan tidur, penggunaan obat tidur dan disfungsi aktivitas siang hari. Masing-masing komponen memiliki kisaran nilai 0-3 dengan 0 menunjukkan tidak adanya kesulitan tidur dan 3 menunjukkan kesulitan tidur yang berat. Jumlah skor dari ketujuh komponen ini menghasilkan satu skor global. Semakin kecil skor global, semakin menunjukkan kualitas tidur yang lebih baik.

Instrumen WHOQOL-BREF ini merupakan rangkuman dari World Health Organization Quality of Life (WHOQOL) -100 yang terdiri dari 26 pertanyaan. WHOQOL- BREF terdiri dari dua bagian yang berasal dari kualitas hidup secara menyeluruh dan kesehatan secara umum, dan satu bagian yang terdiri dari 26 pertanyaan yang berasal dari WHOQOL - 100. Menurut Raudhah (2012) untuk menilai (WHOQOL) BREF, maka ada empat aspek yang digabungkan yaitu aspek fisik, psikologis, hubungan sosial, dan lingkungan.

\section{Analisis Data}

Analisis univariat dilakukan pada masing-masing variabel yaitu untuk mendeskripsikan karakteristik responden penelitian yang meliputi umur, jenis kelamin, pendidikan, dan pekerjaan. Hasil analisis data penelitian yang dilakukan oleh peneliti akan disajikan dalam bentuk tabel distribusi frekuensi dan persentase dari tiap variabel. Analisis Bivariat digunakan untuk mengetahui ada tidaknya hubungan antara variabel independen yaitu kualitas tidur terhadap variabel dependen yaitu kualitas tidur. Analisis ini menggunakan chi-square test, dengan $\mathrm{p}$-value $\leq 0,05$ artinya ada hubungan signifikan secara statistik antara variabel independen dan variabel dependen, dan p-value $\geq$ 0,05 yang artinya tidak ada hubungan signifikan secara statistik antara variabel independen dan dependen.

\section{HASIL}

Berdasarkan tabel 1 dapat diketahui bahwa dari 33 responden yang di teliti penderita diabetes melitus yang berjenis kelamin lakilaki lebih banyak yaitu 20 orang $(60,6 \%)$, sebagian besar berumur 60 74 tahun yaitu 29 responden $(87,9 \%)$, pekerjaan responden yang paling dominan atapun yang paling banyak adalah pensiunan yaitu sebanyak 20 responden $\quad(60,6 \%)$, tingkat pendidikan responden yang paling banyak adalah lulusan SMA yaitu sebanyak 15 responden (45,5\%), kualitas tidur yang paling banyak adalah kualitas tidur buruk dengan jumlah 19 responden $(57,6 \%)$, kualitas hidup paling banyak adalah kualitas hidup buruk dengan jumlah 19 responden $(57,6 \%)$.

Hasil analisis bivariat diketahui responden dengan kualitas tidur baik dan kulitas hidup baik terdiri dari 8 responden $(57,1 \%)$, sedangkan responden dengan kualitas tidur sedang dan kualitas hidup baik terdiri dari 6 responden $(42,9 \%)$, sementara responden yang memiliki 
kualitas tidur buruk dengan kualitas hidup buruk berjumlah 19 responden (100\%). Berdasarkan uji statistic Chi Square diperoleh nilai P-value $(0,000)$. Hal ini menunjukan tingkat kemaknaan $(\mathrm{p} \leq 0,05)$ yang berarti terdapat hubungan yang signifikan antara kualitas tidur dengan kualitas hidup (Tabel 2). Dengan demikian peneliti meyimpulkan bahwa semakin buruk kualitas tidur seseorang maka semakin rendah pula kualitas hidup orang tersebut. Sebaliknya semakin baik kualitas tidur seseorang maka semakin tinggi pula kualitas hidup orang tersebut.

Tabel 1. Distribusi Frekuensi Karakteristik Responden pada Lansia dengan Diabetes Mellitus Tipe 2 ( $\mathrm{n}=33$ )

\begin{tabular}{lcc}
\hline Karakteristik Responden & Frequency (n) & Persentase (\%) \\
\hline Jenis Kelamin & 20 & 60,6 \\
Laki-Laki & 13 & 39,4 \\
Perempuan & & \\
Usia & 29 & 87,9 \\
60-74 Tahun & 4 & 12,1 \\
75-90 Tahun & & \\
Pekerjaan & 5 & 15,2 \\
Swasta & 8 & 24,2 \\
Ibu Rumah Tangga & 20 & 60,6 \\
Pensiun & & \\
Tingkat Pendidikan & 6 & 18,2 \\
SMP & 15 & 45,5 \\
SMA & 12 & 36,4 \\
S1/S2 & & \\
Kualitas Tidur & 8 & 24,2 \\
Baik & 6 & 18,2 \\
Sedang & 19 & 57,6 \\
Buruk & & \\
Kualitas Hidup & 14 & 42,4 \\
Baik & 19 & 57,6 \\
Buruk & &
\end{tabular}

Tabel 2. Analisis Hubungan Kualitas Tidur dengan Kualitas Hidup pada Lansia dengan Diabetes Mellitus Tipe $2(\mathrm{n}=33)$

\begin{tabular}{|c|c|c|c|c|c|c|c|}
\hline \multirow{3}{*}{$\begin{array}{c}\text { Kualitas } \\
\text { Tidur }\end{array}$} & \multicolumn{4}{|c|}{ Kualitas Hidup } & \multirow{2}{*}{\multicolumn{2}{|c|}{ Total }} & \multirow{3}{*}{$\begin{array}{r}\text { P-Value } \\
0,000\end{array}$} \\
\hline & \multicolumn{2}{|c|}{ Baik } & \multicolumn{2}{|c|}{ Buruk } & & & \\
\hline & $\mathrm{F}$ & $\%$ & $\mathrm{~F}$ & $\%$ & $\mathrm{~F}$ & $\%$ & \\
\hline Baik & 8 & 57,1 & 0 & 0 & 8 & 100 & \\
\hline Sedang & 6 & 42,9 & 0 & 0 & 6 & 100 & \\
\hline Buruk & 0 & 0 & 19 & 100 & 19 & 100 & \\
\hline Total & 14 & 100 & 19 & 100 & 33 & 100 & \\
\hline
\end{tabular}

\section{PEMBAHASAN}

Kualitas tidur lansia yang mengalami DM tipe 2 menjadi salah satu penentu kualitas hidupnya. Hasil penelitian ini didukung oleh Pereira (2014) yang meneliti hubungan pola tidur dengan kualitas hidup lansia. 
Penelitian ini menyimpulkan bahwa ada hubungan korelasional pola tidur dengan kualitas hidup lansia. Seseorang yang memasuki usia lanjut akan mengalami perubahan secara bertahap didalam aktivitas metabolisme organ dan dimulainya ketidakmampuan tubuh dalam meregenerasi sel. Dampak dari perubahan tersebut yaitu lansia mengalami penurunan aspek-aspek dalam kualitas hidup. Salah satu prediktor utama dalam kualitas hidup adalah kesehatan fisik, dimana salah satunya yaitu aspek tidur dan istirahat (Edwina, et.al, 2015; Rachmawati, 2013; Wafy, 2014). Tidur merupakan salah satu fenomena dasar yang penting bagi kehidupan manusia, kurang lebih dari 7 jam kehidupan manusia dijalankan dengan tidur (Gustimigo, 2015). Menurut Tamber (2009) proses degenerasi pada lansia menyebabkan waktu tidur yang efektif semakin berkurang, dan menyebabkan tidak tercapainya kualitas tidur yang adekuat dan menyebabkan berbagai macam keluhan tidur yang dapat mengakibatkan penurunan pada kualitas hidup lansia (Rotie, 2017). Sejalan dengan penelitian Ardinata (2014) diketahui bahwa ternyata kualitas tidur ada hubungannya dengan kesehatan fisik, salah satunya yaitu peningkatan tekanan darah.

Pasien dengan penyakit diabetes melitus, saat tidur malam hari pankreas akan melepaskan secara terus menerus sejumlah kecil insulin bersama dengan hormon pankreas lain yang disebut dengan glukagon. Insulin dan glukagon secara bersama-sama mempertahankan kadar glukosa yang konstan dalam darah dengan menstimulasi pelepasan glukosa dari hati. Jika kadar glukosa tinggi dalam darah dan jumlah insulin berkurang maka jumlah glukosa yang memasuki sel akan berkurang yang akan menyebabkan produksi glukosa oleh hati menjadi tidak terkendali. Dalam upaya untuk menghilangkan glukosa yang berlebihan dari dalam tubuh, ginjal akan mengekresikan glukosa bersama air dan elektrolit. Hal inilah yang menyebabkan urinasi yang berlebihan (poliuria) dan panas pada malam hari dan merasakan peningkatan rasa haus (polidipsi) sehingga menyebabkan lansia sering terbangun di malam hari ditambah lagi akibat dari proses degenerasi yang dialami lansia membuatnya susah untuk memulai tidur. Hal inilah yang menyebabkan kualitas tidur pada lansia terganggu yang mengakibatkan terjadinya penurunan pada kualitas hidupnya.

\section{SIMPULAN}

Terdapat hubungan yang signifikan antara kualitas tidur dengan kualitas hidup lansia dengan penyakit DM tipe 2. Semakin buruk kualitas tidur lansia maka akan semakin rendah kualitas hidupnya.

\section{SARAN}

Lansia yang mempunyai penyakit DM tipe 2 disarankan untuk menjaga kualitas tidurnya agar kualitas hidupnya juga menjadi lebih baik. Sedangkan bagi petugas kesehatan khususnya perawat disarankan untuk memberikan intervensi untuk meningkatkan kualitas tidur pada lansia yang mengalami DM tipe 2. Dengan demikian maka kualitas hidup lansia dapat ditingkatkan menjadi lebih baik. 


\section{DAFTAR PUSTAKA}

American Diabetes Association (ADA) (2015). Diagnosis and classification of diabetes mellitus. Vol.38, pp: 8-16

Al-Maskari M., Al-Shookri A., AlAdawi S., Lin K. (2011). Assessment of quality of life in patients with type 2 diabetes mellitus in oman, Saudi Med J . Vol. 32 (12): 1285-1290.

Ardinata, D. (2013). Hubungan antara kualitas tidur dengan peningkatan tekanan darah. Karya Tulis Ilmiah, Fakultas Kedokteran Universitas Sumatera Utara, Sumatera

Bustan. (2015). Manajemen pengendalian penyakit tidak menular. Jakarta: Rineka Cipta

Chang, E. Daly, J, dan Elliott, D. (2010). Patofisiologi Aplikasi Pada Praktik Keperawatan, 112-113. Jakarta: EGC

Dinas Kesehatan. 2017. Profil Kesehatan Kota Palangkaraya. Dinas Kesehatan Palangkaraya

Edwina, DA., Manaf, A., Efrida, et al. (2015). Pola komplikasi kronis penderita diabetes melitus tipe 2 rawat inap di bagian penyakit dalam RS. dr. M. Djamil Padang Januari 2011-Desember 2012. Jurnal Kedokteran Andalas. 4(1): 102-106.

Gustimigo, Z.P. (2015). Kualitas tidur penderita diabetes mellitus. Fakultas Kedokteran Universitas Lampung

Rachmawati, Suhardiana. (2013). Kualitas hidup orang dengan
HIV/AIDS yang mengikuti antiretroviral. Jurnal Sains dan Praktik Psikologi. Vol. 1(1), (48-62).

Rahayu, Dwi Yulianti. (2015). Hubungan dukungan keluarga dengan kualitas hidup lansia di desa Pungung Rejo Purworejo. STIKES Aisyiah Yogyakarta

Raudhah, I. (2012). kualitas hidup lansia di Graha Residen Senior Karya Kasih Medan Sumatera Utara. Skripsi Fakultas Keperawatan USU Medan

Rotie, V. Julia. (2017). Hubungan kualitas tidur dengan kadar glukosa darah puasa pada pasien diabetes melitus tipe 2 di rumah sakit pancaran kasih gmim manado. Universitas Sam Ratulangi Manado

Wavy, W. W. Y. (2014). The relationship between time management, perceived stress, sleep quality and academic performance among university students. Tesis (tidak diterbitkan). Hong Kong Baptist University

World Health Organization (WHO). 2004. WHOQOL-BREF: Intrduction Administration, Scoring and Generic Version of The Assesment. Geneva: World Health Organization (WHO)

Yudianto, Kurniawan, et all. (2008). Kualitas Hidup Penderita Diabetes Melitus Di Rumah Sakit Umum Daerah Cianjur. jurnal Keperawatan, 76 